\title{
Zaufanie jako czynnik skuteczności projektu interimowego
}

\author{
Dr hab. Beata Skowron-Mielnik, prof. UEP \\ Uniwersytet Ekonomiczny w Poznaniu \\ Dr Grzegorz Sobiecki \\ BMPS Consulting
}

\section{Wprowadzenie}

Tymczasowe zarządzanie jest formą zatrudnienia, w której organizacja zatrudnia wysoce wyspecjalizowanego eksperta na określony czas i do realizacji określonego celu, na przykład rozwiązania konkretnego wyzwania w okresie kryzysu. Interim management może opierać się na różnych koncepcjach zatrudnienia: menedżer tymczasowy może zostać pracownikiem organizacji przyjmującej, pracować dla niej jako kontrahent na podstawie prawa gospodarczego lub może być zaangażowany jako osoba trzecia (podobnie jak agencja pracy tymczasowej zatrudnia tymczasowego menedżera i przekazuje go spółce przejmującej). Tymczasowe zarządzanie jest uważane za elastyczną formę pracy, bez długoterminowych zobowiązań. Przedsiębiorstwo może je zastosować, aby odpowiedzieć na zapotrzebowanie na heterogeniczną siłę roboczą, która może zapewnić rozwiązania oparte na fachowej wiedzy i przez ograniczony czas ${ }^{1}$. Interim management to także zapewnianie zewnętrznego personelu kierowniczego, odpowiedzialnego za projekt interimowy, czyli za czasowe, zdefiniowane co do celu i zakresu działanie wewnątrz organizacji, nastawione na osiągnięcie konkretnych i trwałych rezultatów biznesowych ${ }^{2}$, różniące się od świadczenia usług konsultingowych, ponieważ tymczasowy menedżer ma pewne uprawnienia do kierowania

1 K. Inkson, A. Heising, D.M. Rousseau, The interim manager: Prototype of the 21st-century worker?, „Human Relations” 2001, vol. 54, no. 3, s. 259-284; R. Isidor, C. Schwens, R. Kabst, Interim management utilization, firm flexibility and its impact on firm performance, „International Journal of Human Resources Development and Management" 2014, vol. 14, no. 4; Eurofound, New forms of employment, Publications Office of the European Union, Luxembourg 2015, eurofound.link/ef1461 (dostęp: 20.10.2019); Eurofound, Overview of new forms of employment - 2018 update, Publications Office of the European Union, Luxembourg 2018, eurofound.link/ef18050 (dostęp: 20.10.2019).

2 Metodyka Interim Management, Stowarzyszenie Interim Managers, Warszawa 2014, s. 11. 
(na podstawie wyznaczonych zadań) i podlega (ograniczonym) instrukcjom³ ${ }^{3}$. W związku z tym, w porównaniu z zewnętrznymi konsultantami, tymczasowi menedżerowie są w pewnym stopniu zintegrowani $\mathrm{z}$ siłą roboczą organizacji przyjmującej, choć zazwyczaj nie w takim samym stopniu jak stali menedżerowie. Tymczasowość relacji, specjalistyczna wiedza oraz zadaniowość są kluczowymi cechami w postrzeganiu i kształtowaniu roli interim menedżera.

Interim to przymiotnik określający coś tymczasowego, przejściowego, doraźnego, zastępczego, chwilowego, czasowego, substytutywnego. $Z$ definicji zatem obiekt określany przymiotnikiem interim (kimkolwiek lub czymkolwiek jest) od początku do końca trwania ma charakter zadaniowy i terminowy. W przypadku projektów interimowych i zarządzających nimi osób - interim menedżerów - zasadne wydaje się poruszenie kwestii konsekwencji tej tymczasowości. W tym przypadku realizacji zadań menedżerskich - wyraźnie określonych czasowo, często w niepracowniczej formie zatrudnienia, o charakterze doradczym, ale też z ponoszeniem odpowiedzialności za konkretnie postawiony cel - mogą pojawić się problemy z podziałem władzy w organizacji. Zwłaszcza w sytuacji, kiedy organizacja decyduje się na tymczasowe zaoferowanie stanowiska menedżera osobie z zewnątrz, dopóki nie znajdzie kandydata na stałe lub nie wróci dotychczasowy pracownik. Podjęte próby zdefiniowania interim managementu ${ }^{4}$, ale też praktyka biznesowa ${ }^{5}$, wskazują na to, że jest to jednak usługa komplementarna w stosunku do dotychczasowego systemu zarządzania, a interim menedżer wnosi wartość dodaną do zarządzanej organizacji. Jeśli umownie podzielić potrzeby organizacji biznesowej na operacyjne oraz strategiczne, to interim management nie skupia się na potrzebach nakierowanych na utrzymanie standardowego modelu biznesowego i realizację bieżących zadań, ale ma doprowadzić do modyfikacji lub wręcz transformacji modelu, albo też jego obrony w sytuacjach kryzysowych. W związku z tym istotne wydaje się znaczenie wiedzy wykraczającej ponad tę, którą ma organizacja, oraz wiedzy o organizacji, którą musi zdobyć interim menedżer, żeby skutecznie realizować postawione zadania. Ograniczony czas trwania projektu i presja na jego efekt powodują, że interim menedżer od momentu rozpoczęcia projektu powinien mieć odpowiedni zakres władzy, oddanej przez właściciela lub głównego zarządzającego.

3 J. Bruns, R. Kabst, Interim-management: A paradox for leadership research?, „Management Revue" 2005, vol. 15, s. 512-524.

4 B. Skowron-Mielnik, M. Bądzio, Interim management jako forma doskonalenia biznesowego i zawodowego, „Zeszyty Naukowe Politechniki Śląskiej”, seria „Organizacja i Zarządzanie” 2016, z. 97, s. 449-460.

5 Metodyka Interim...; Interim Management w Polsce. Raport z badania zrealizowanego w 2018 roku, Stowarzyszenie Interim Managers, Warszawa 2019, http://stowarzyszenieim .org/public/www/media/File/2019/Raport\%20z\%20badania\%20rynu\%20interim\%20ma nagement\%202019.pdf (dostęp: 27.01.2020). 
Władza ta powinna być połączona $z$ autorytetem, w sensie przyzwolenia na jej sprawowanie ze strony zespołu, który ma świadomość tymczasowości tej władzy. Niekiedy klienci, korzystając z usług interim menedżera, nie informują pracowników o charakterze tego zatrudnienia, zakładając, że nie będzie traktowany wystarczająco poważnie, tymczasowość zatrudnienia nie wzbudza bowiem zaufania. To wskazuje na trzeci czynnik skuteczności, jakim jest zaufanie. Zwraca się też uwagę na umiejętność diagnozowania zaufania jako kompetencję interim menedżera do odkrywania panujących w organizacji stosunków, opartych na zaufaniu, i określania poziomu zaufania w tych relacjach ${ }^{6}$.

O ile wiedza jest atrybutem głównie interim menedżera, a władza organizacji, to zaufanie powinno być obustronne. Władza nie zostanie oddana przez przedsiębiorcę, a udostępnianie wiedzy przez interim menedżera będzie ograniczone, jeśli strony relacji biznesowej, z jaką jest związany projekt interimowy, nie będą miały do siebie zaufania. Zaufanie jest pewnego rodzaju katalizatorem dla dwóch pozostałych kategorii czynników ${ }^{7}$. Zastosowane podejście metodyczne nawiązuje do teorii ugruntowanej, czyli budowania teorii na podstawie systematycznie zbieranych danych empirycznych. Teoria jest tutaj pochodną analiz danych empirycznych i wyłania się, w trakcie systematycznie prowadzonych badań terenowych, z danych empirycznych, które bezpośrednio odnoszą się do obserwowanej części rzeczywistości społecznej ${ }^{8}$. Autorzy zbudowali program badawczy empiryczno-indukcyjny ${ }^{9}$, który łączy trzy powyższe kategorie czynników skuteczności projektu interimowego: zaufanie, władzę oraz wiedzę (rysunek 1).

Powstają zatem pytania o znaczenie zaufania w koncepcji czynników skuteczności projektu interimowego, o jego charakter i sposób budowania, biorąc pod uwagę uświadomioną przez organizację tymczasowość, krótki okres trwania projektu, a tym samym brak czasu na długookresowe budowanie relacji opartej na zaufaniu.

6 M. de Weerd, The knowledge gap of interim management, Paper presented at $5^{\text {th }}$ IBA Bachelor Conference 2015, July, $2^{\text {nd }}$, University of Twente, The Faculty of Behavioural, Management of Social Sciences, Enschede, The Netherlands, https://essay.utwente.nl/67386/1/de \%20Weerd_BA_Management\%20\%26\%20Governance.pdf (dostęp: 9.01.2020).

7 Szersze omówienie koncepcji badań nad czynnikami skuteczności autorzy zawarli w artykule pt. Effectiveness factors in interim management projects - research concept, Scientific Papers of Silesian University of Technology, Organization and Management Series [w trakcie recenzji].

8 B.G. Glaser, A.L. Strauss, Odkrywanie teorii ugruntowanej. Strategie badania jakościowego, Zakład Wydawniczy Nomos, Kraków 2009.

9 Badania prowadzone są od 2018 roku przez autorów niniejszego artykułu w ramach wspótpracy między Uniwersytetem Ekonomicznym w Poznaniu a Stowarzyszeniem Interim Managers w Warszawie. 


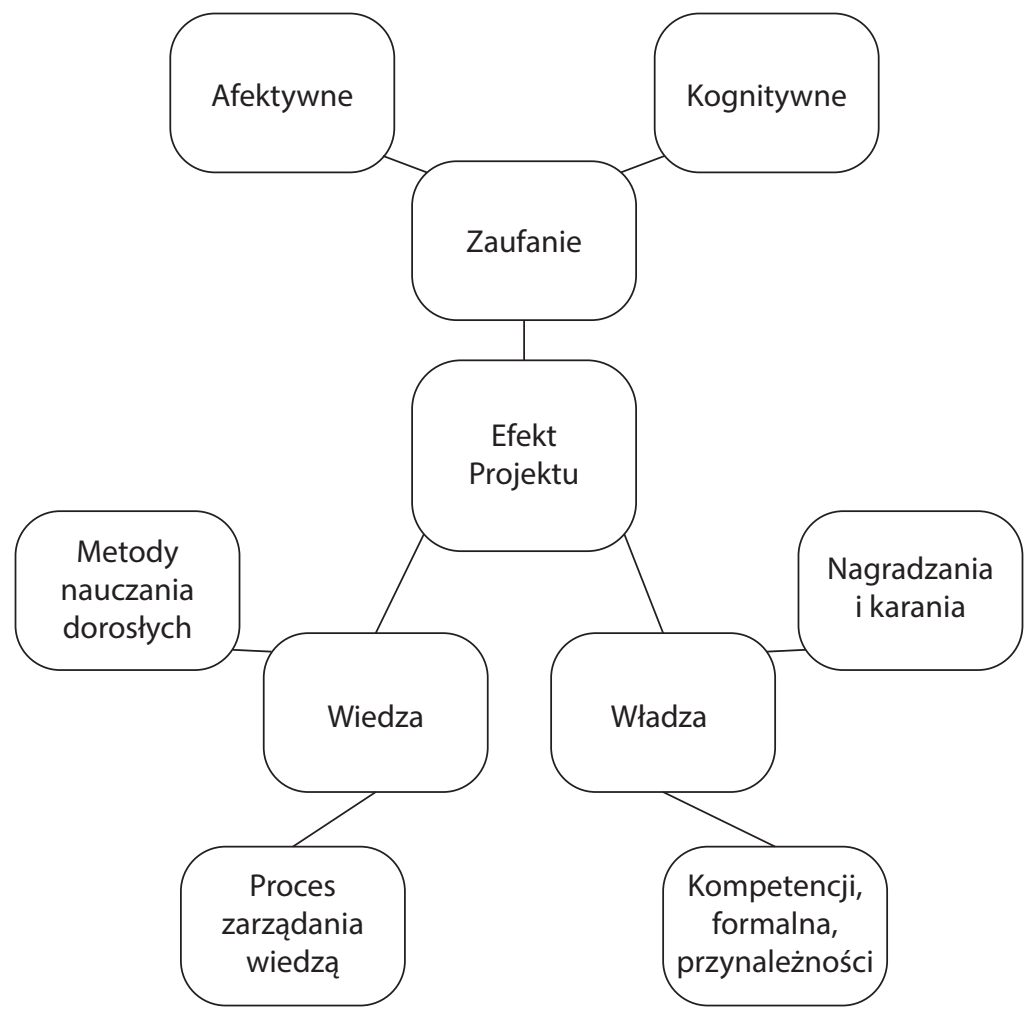

Rysunek 1. Czynniki skuteczności projektu interimowego

Źródto: opracowanie własne.

\section{Kategoria zaufania w projektach z zakresu interim management}

Cechą zaufania w relacjach biznesowych jest wielowymiarowość, może ono mieć bowiem miejsce zarówno między ludźmi reprezentującymi organizacje (wymiar interpersonalny), jak i między firmami (wymiar organizacyjny) ${ }^{10}$. W naukach o zarządzaniu zaufanie ujmowane jest w czterech głównych nurtach - jako ${ }^{11}$ :

- interpersonalne zaufanie wewnątrzorganizacyjne między przełożonymi i podwładnymi oraz między współpracownikami,

10 O. Schilke, K.S. Cook, A cross-level process theory of trust development in interorganizational relationships, „Strategic Organization” 2013, no. 11(3).

11 D. Lewicka, K. Krot, D. Książek, Metodyczne aspekty badania zaufania w naukach o zarzadzaniu, „Zeszyty Naukowe Uniwersytetu Ekonomicznego w Krakowie” 2016, nr 7(955). 
- impersonalne, instytucjonalne zaufanie wewnątrzorganizacyjne pracowników do organizacji,

- zaufanie w relacjach międzyorganizacyjnych (interorganizacyjne),

- w obszarze marketingu zaufanie klientów do organizacji, a także do zakupów online.

Zaufanie to konstrukt koncepcyjny niejednoznacznie zdefiniowany, istotny oraz powracający w badaniach, jeśli chodzi o skuteczność zarządzania. Handfield i Betchel, których badanie objęło 39 publikacji peer reviewed (istotność) oraz 41 lat (1958-1999 - powracanie tematu), wykazują osiem koncepcji zaufania (niejednoznaczność) $^{12}$. Jednakże pomijają oni aspekt interim management. W innym przeglądzie bibliograficznym, który obejmuje ponad 600 publikacji o zaufaniu, wyodrębniono 336, które spełniają następujące wymogi: „częstotliwość cytowania, bezpośrednie odniesienie do konceptu zaufania w tytule lub streszczeniu, lub zastosowanie zaufania jako kluczowego konstruktu w publikacji"13. Autor przeglądu stwierdza, że: „źródła są rozrzucone pomiędzy wieloma dziedzinami wiedzy: socjologią, psychologią, etyką, polityką, IT, zachowaniami organizacyjnymi, strategią oraz marketingiem"14. Dlatego zauważalna jest luka badawcza, a niniejszy artykuł stanowi próbę jej wypełnienia. Dobór literatury w niniejszym opracowaniu skupiony został wokół dopasowania do specyfiki pracy interim menedżera: tymczasowości, obcości w organizacji klienta, relacyjności oraz obaw i szans w zatrudnianiu.

Bauer i Freitag ujmują zaufanie w podejściu oczekiwań oraz sytuacyjnym, według którego „osoba ufająca A ufa osobie B (ocenia wiarygodność osoby B) w odniesieniu do zachowań X w kontekście Y w momencie (czasie) T"15. Na poparcie tych propozycji przytaczają dane pozyskane z około 1100 odpowiedzi z badań przeprowadzonych w roku 2012 w Szwajcarii. Struktura odpowiedzi odnoszących się do osób znanych respondentom lub z nimi spokrewnionych jest przesunięta w stronę wysokiego poziomu zaufania (100\%) oraz reprezentuje skoncentrowany i wysoki odsetek odpowiedzi. Z kolei struktura odpowiedzi, które odnoszą się do większości ludzi lub do obcych ludzi, jest przesunięta w stronę średniego i niskiego (obcy) poziomu zaufania i reprezentuje rozproszony oraz niski odsetek odpowiedzi. Status

12 R.B. Handfield, Ch. Betchel, Trust, power, dependence, and economics: can SCM research borrow paradigms?, „International Journal of Integrated Supply Management” 2004, vol. 1(1).

13 D. Arnott, Research on Trust: A Bibliography and Brief Bibliometric Analysis of the Special Issue Submissions, „European Journal of Marketing” 2007, vol. 41(9/10), s. 1203.

14 Tamże.

15 P. C. Bauer, M. Freitag, Measuring Trust, Chapter prepared for the The Oxford Handbook of Social and Political Trust, Edited by Eric M. Uslaner, Oxford University Press, Oxford 2016, s. 1-2, https://papers.ssrn.com/sol3/papers.cfm?abstract_id=2852755 (dostęp: 10.03.2019). 
interim menedżera jest bliższy postrzeganiu go jako osoby obcej lub co najmniej mało znanej, co szczególnie w przypadku pierwszego kontaktu z daną organizacją nie stwarza podstaw do zaufania. Należy zwrócić uwagę na to, że zaufanie w relacji interim menedżer - organizacja kształtuje się nie tylko na linii interim menedżer - klient, ale też interim menedżer - zespół pracowników. O ile w przypadku klienta wzrastać może prawdopodobieństwo, że zna interim menedżera, którego wybiera do realizacji zadania - na podstawie rekomendacji oraz referencji lub dzięki znajomości z poprzednich projektów realizowanych w tej samej organizacji, o tyle pracownicy go nie znają. Zaufaniem najczęściej darzymy tych, których znamy, z którymi już wspólnie działaliśmy i których kompetencje poznawcze (wiedza), organizacyjne (sprawność w działaniu), a przede wszystkim moralne (uczciwość i rzetelność) jesteśmy w stanie ocenić jako wiarygodne ${ }^{16}$. Hardin twierdzi, że o naszym zaufaniu do kogoś decyduje wiedza o moralnym zaangażowaniu osób generujących związek oparty na zaufaniu albo też wiedza o ich psychologicznych, charakterologicznych skłonnościach, tak więc by obdarzyć kogoś zaufaniem, należy dysponować określoną wiedzą na jego temat, znać go, sprawdzić jego zachowanie $\mathrm{w}$ działaniu, w ekstremalnych warunkach ${ }^{17}$. Tymczasowość i z reguły krótkotrwałość projektu interimowego nie sprzyjają takiemu poznaniu ${ }^{18}$.

Z kolei Robbins i Judge ujmują zaufanie z perspektywy oczekiwań oraz szczególnie jako relację pomiędzy liderem transformacyjnym i podwładnym ${ }^{19}$. Biorąc pod uwagę to, że interim management jest traktowany jako koncepcja zarządzania $\mathrm{w}$ okresie czy na rzecz transformacji organizacji, to interim menedżer powinien być liderem transformacyjnym. Wychodząc z tej perspektywy, Robbins i Judge twierdzą, że:

- „zaufanie jest to stan psychologiczny, który istnieje wówczas, gdy ktoś zgodnie przyjmuje zależność od innej osoby, ponieważ posiada pozytywne oczekiwania co do rozwoju wypadków;

- pozbawiając się kontroli sytuacji, osoba podejmuje ryzyko tego, że ktoś inny przeprowadzi kontrolę za nią. [...] Zaufanie jest więc pierwotnym atrybutem związanym z przywództwem;

- przywódcy transformacyjni [...] wytwarzają wsparcie dla swych planów, podając argumenty, dlaczego ich kierunek działania będzie spełniał interesy

16 A. Drabarek, Zaufanie jako podstawowa wartość przestrzeni publicznej w wymiarze lokalnym, „Studies in Global Ethics and Global Education” 2014, no. 2, s. 3-11.

17 R. Hardin, Zaufanie, Wydawnictwo Sic!, Warszawa 2009, s. 26.

18 Z danych Stowarzyszenia Interim Managers wynika, że są to w większości projekty trwające do 6 miesięcy (Interim Management w Polsce...).

19 S.P. Robbins, T.A. Judge, Organizational Behavior, $17^{\text {th }}$ Edition, Pearson Education Limited, Edinburgh Gate, Harlow 2017, s. 440-442. 
wszystkich. [...] Stąd, jak można oczekiwać, przywódcy transformacyjni wytwarzają wyższy poziom zaufania wśród swoich podwładnych"20.

Autorzy ci podają również propozycje czynników budowania stanu zaufania, wymieniając:

- spójność jako pojęcie, które odnosi się do uczciwości oraz szczerości lub prawdomówności,

- dobroć, co oznacza, że osobie obdarzonej zaufaniem leży na sercu interes osoby ufającej,

- zdolność do czegoś, co obejmuje wiedzę oraz umiejętności w sensie technicznym oraz interpersonalnym,

- skłonność, oznaczającą, z jakim prawdopodobieństwem pracownik zaufałby liderowi,

- czynnik czasu, który pokazany jest z trzech perspektyw: zachowań (zbliżamy się do stanu zaufania, obserwując zachowanie danej osoby w czasie), kompetencji (zaufanie można zyskiwać, wykazując kompetencje), komunikacji (liderzy mogą zbudować zaufanie przez zamianę odgórnych poleceń na codzienny dialog z organizacją).

Jeśli chodzi o czynniki budowania stanu zaufania, to zbieżne z obserwacjami Robbinsa i Judge'a wydają się propozycje Zengera i Folkmana. Autorzy ci, na podstawie wyników oceny 360 stopni wśród 87000 liderów, wymieniają trzy czynniki 21 :

- pozytywne relacje - równowaga skupienia na wynikach oraz trosce o innych, budowanie współpracy $\mathrm{z}$ innymi itp.;

- bycie ekspertem - prezentowanie właściwej oceny sytuacji; wiedza i specjalizacja lidera wnoszą wkład do efektów, inni kierują się opiniami lidera;

- spójność słów z czynami, przestrzeganie własnych zobowiązań.

W powyższych czynnikach przejawia się postrzeganie zaufania przez pryzmat dwóch komponentów: kognitywnego, który obejmuje ocenę kompetencji i życzliwości drugiej strony, oraz afektywnego, obejmującego elementy emocjonalne. Akrout i Akrout podkreślają rolę zaufania o charakterze kalkulatywnym na początku relacji, które jest efektem kognitywnego zestawienia oczekiwanych zysków $z$ relacji z kosztami budowania i rozwijania współpracy oraz reputacji partnera 22 . Wraz z czasem i kolejnymi interakcjami między zaangażowanymi stronami pojawia się zaufanie o charakterze afektywnym, a oba rodzaje wspierane są przez zaufanie o podłożu instytucjonalnym (reputacja firmy, jej kultura oraz procesy).

20 Tamże.

21 J. Zenger, J. Folkman, The 3 Elements of Trust, „Harvard Business Review” 2019, February 5, https://hbr.org/2019/02/the-3-elements-of-trust (dostęp: 28.01.2020).

22 P. Gaczek, G. Leszczyński, M. Zieliński, Afektywne a kalkulatywne zaufanie przed nawiq̨zniem relacji biznesowych, „Handel Wewnętrzny” 2018, nr 3(374), s. 127-137. 
W przypadku projektów interimowych oba wymiary (tj. kognitywny i afektywny) wydają się wywierać wpływ na skuteczność projektu w odniesieniu do jego przebiegu i końcowych efektów. Patrząc na zaufanie przez pryzmat czasu trwania relacji, autorzy proponują założenie, że zaufanie rozwija się wraz z trwaniem relacji, tak więc dla osiągnięcia wysokiego poziomu zaufania potrzebny jest czas oraz historia interakcji między stronami ${ }^{23}$, a te nie są $\mathrm{w}$ projektach interimowych długie.

Jednocześnie należy podkreślić, że budowanie zaufania w projekcie interimowym zachodzi między trzema podmiotami: interim menedżerem (IM), klientem oraz zespołem, czyli pracownikami (rysunek 2). Każda z tych relacji ma inny charakter, kształtuje się w innej perspektywie czasu i zależności między podmiotami, co tworzy charakterystyczną dla tego typu projektów perspektywę badawczą. Jednocześnie to interim menedżer wydaje się w tym układzie najbardziej istotnym podmiotem budującym i sterującym zaufaniem, ponieważ to on odpowiada za efekt projektu interimowego.

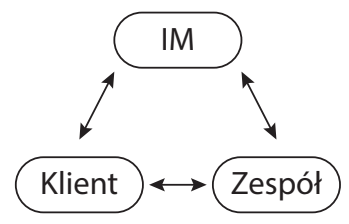

Rysunek 2. Relacje w budowaniu zaufania w projekcie interimowym

Źródto: opracowanie własne.

W odniesieniu do oceny wielkości znaczenia zaufania dla efektywności działań organizacyjnych próbę stwierdzenia zależności między nimi (tj. zaufaniem a efektem) podjęli Łobos i Mazur, którzy w wyniku przeglądu literatury wskazali 17 pozycji literaturowych dotyczących skutków zaufania międzyorganizacyjnego ${ }^{24}$. Efektywność stanowiła tu zmienną zależną. Autorzy ci przeanalizowali 31 pomiarów efektywności oraz jej korelacji z zaufaniem międzyorganizacyjnym. Łącznie dla wszystkich 17 pozycji suma wielkości wszystkich prób wyniosła 4412 przypadków, w których odpowiednio 25 razy, 6 razy oraz 9 razy wystąpił miernik efektywności procesowej, miernik efektywności finansowej oraz miernik efektywności społecznej. Jedynie w 5 na 31 pomiarów (ze wszystkich

23 R.J. Lewicki, E.C. Tomlinson, N. Gillespie, Models of interpersonal trust development: Theoretical approaches, empirical evidence, and future directions, „Journal of Management” 2006, no. 32(6).

24 K. Łobos, K. Mazur, Wskaźniki zaufania w badaniach nad zaufaniem międzyorganizacyjnym, „Finanse, Rynki Finansowe, Ubezpieczenia” 2016, nr 1(79), s. 809-817, https://wneiz.pl/na uka_wneiz/frfu/79-2016/FRFU-79-809.pdf (dostęp: 7.09.2019). 
17 wyodrębnionych pozycji) związek efektywności z zaufaniem określono na podstawie danych finansowych. Zmierzono w ten sposób następujące parametry finansowe: wzrost sprzedaży, efektywność finansową partnera, wzrost zysku, efektywność finansową eksportu, wzrost sprzedaży (oddzielny przypadek od pierwszego). Tak więc w ponad 80\% przypadków związek ten wykazano za pomocą kwestionariusza ze skalą Likerta. Wśród nich 24 pomiary reprezentowały miernik efektywności procesowej. Efektywność ekonomiczna wykazuje więc związek z zaufaniem, a zaufanie z perspektywy ekonomicznej jest dobrem o rzeczywistej wartości. W teorii kosztów transakcyjnych zaufanie jest substytutem mechanizmów kontroli oraz koordynacji i może prowadzić do obniżenia kosztów transakcyjnych 25 .

Autorzy niniejszego badania przyjmują jako zmienną nie efektywność, lecz skuteczność projektu, gdzie miarą skuteczności jest procentowe wykonanie celu projektu.

\section{Metodyka badań}

Jak wcześniej wspomniano, podejście metodyczne nawiązuje do teorii ugruntowanej. Program badawczy oparty na kategoriach zaufania, władzy oraz wiedzy wymaga wielokrotnego przeprowadzenia badań na populacji projektów interimowych w realnych organizacjach biznesowych, by stwierdzić, w jakim stopniu zastosowanie rozwiązań interim management powiązane jest ze skutecznością projektu, czyli spełnieniem potrzeb organizacji, zdefiniowanych dla każdego z projektów.

Kierunek doboru instrumentu badawczego uwzględniał następujące kryteria:

- reprezentowanie fachowości, kompetencje, bycie ekspertem,

- spójność i przewidywalność słów i działań, inaczej określane jako wiarygodność,

- budowanie relacji w równowadze między dążeniem do wyniku a troską o ludzi,

- uwzględnienie czynnika czasu w budowaniu zaufania, który jest szczególnie istotny wobec przebywania interim menedżera $\mathrm{z}$ klientem i organizacją klienta w trakcie kilkumiesięcznego projektu interimowego.

Istotne było także rozstrzygnięcie, czy zaufanie należy zbadać innym instrumentem dla decydentów-klientów oraz oddzielnym instrumentem dla organizacji klienta (zespół), oraz czy w ogóle włączać dwa powyższe podmioty, czy też jeden. Zleceniodawca będzie bowiem podejmował decyzje kluczowe dla projektu oraz

25 M. Zieliński, Zaufanie w relacjach business-to-business. Perspektywa dynamiczna, Wydawnictwo Uniwersytetu Ekonomicznego w Poznaniu, Poznań 2019, s. 47. 
interim menedżera: zawarcie kontraktu, zatwierdzanie etapów projektu i budżetów, wreszcie delegowanie własnych pracowników oraz innych zasobów do projektu. Ważniejszym elementem powodzenia projektu interimowego wydaje się zatem zaufanie klienta. Jednakże efekty, które interim menedżer w projekcie może osiągać przez umiejętność zaangażowania załogi klienta w tymczasowy projekt, wskazują na konieczność zbadania obu podmiotów.

Przegląd istniejących w literaturze podejść do pomiaru zaufania pozwolił na analizę instrumentów stosowanych dotychczas w badaniach poprzez porównanie obecności w nich wskazanych wyżej czterech kryteriów. McEvily and Tortioriello, na podstawie bibliometrycznej analizy 171 pozycji opublikowanych w ciągu 48 lat, wyodrębnili pięć instrumentów badawczych, których stosowanie ma najsilniejsze podstawy statystyczne (współczynnik Alfa Cronbacha), a ich konstrukcja odpowiada założeniom wielowymiarowości zaufania ${ }^{26}$ : McAllistera, Cummingsa i Bromileya, Mayera i Davisa, Curralla i Judge’a oraz Gillespiego. Wobec wysokiego poziomu ufności statystycznej oraz silnej współbieżności z przyjętymi wcześniej czterema kryteriami dla instrumentu badawczego zaufania względem interim managementu instrument opublikowany przez McAllistera ${ }^{27}$ (1995) (patrz tabela 1) wydaje się w niniejszym badaniu optymalny do celów badawczych.

Biorąc pod uwagę to, że instrument badawczy został zaprojektowany do relacji równorzędnych między menedżerami, jego zastosowanie do relacji różniących się pod względem władzy jest nieznane, stąd może wynikać jego ograniczenie w badaniu zaufania między interim menedżerem a zespołem, ale też badanie może wskazać na przydatność tego instrumentu w podobnych sytuacjach. Brzmienie niektórych pytań w tym instrumencie rodzi również wątpliwości dotyczące zdolności respondentów do właściwego ustosunkowania się do nich (np. „Większość ludzi ufa mu"). Instrument ten był już jednak wykorzystywany przez innych badaczy w badaniu relacji między liderem a zespołem ${ }^{28}$, stąd decyzja o jego wykorzystaniu.

26 B. McEvily, M. Tortoriello, Measuring Trust in Organizational Research: Review and recommendations, „Journal of Trust Research” 2011, vol. 1(1), s. 23-63, https://www.tandfonline .com/doi/pdf/10.1080/21515581.2011.552424?needAccess=true (dostęp: 23.11.2019).

27 D.J. McAllister, Affect-and-cognition-based trust as foundations for interpersonal cooperation in organizations, „Academy of Management Journal” 1995, vol. 38(1), s. 24-59.

28 T.-Y. Kim, J. Wang, J. Chen, Mutual trust between leader and subordinate and employee outcomes, „Journal of Business Ethics” 2018, vol. 149, issue 4, s. 945-958, https://www.resea rchgate.net/publication/294674500_Mutual_Trust_Between_Leader_and_Subordinate _and_Employee_Outcomes (dostęp: 22.12.2019). 
Tabela 1. Kwestionariusz badania ankietowego dla zaufania

Instrument badawczy dla zaufania

\section{Szanowny Respondencie,}

- wypełniając niniejszy kwestionariusz, uczestniczysz w badaniu o charakterze naukowym nad zjawiskiem, jakim jest interim management;

- badanie prowadzone jest przez zespół badaczy z Uniwersytetu Ekonomicznego w Poznaniu oraz Stowarzyszenia Interim Managers (SIM) w Warszawie;

- Twoje odpowiedzi, jako osoby, która uczestniczyła w projekcie interimowym, wnoszą niezwykle ważny wkład w odkrycie czynników wpływających na efekt projektu.

Instrukcja wypetniania kwestionariusza

- Zaznacz, proszę, Twoją odpowiedź na każde pytanie, zakreślając liczbę od 1 do 7 po prawej stronie, zgodnie z Twoją opinią co do treści pytania:

1 - zdecydowanie nie, 2 - nie, 3 - raczej nie, 4 - nie mam zdania, 5 - raczej tak, 6 - tak, 7 - zdecydowanie tak

- Wypełniaj odpowiedzi spontanicznie, na podstawie Twojej najlepszej wiedzy.

Anonimowość

- Twoje dane osobowe, Twoje odpowiedzi ani też dane i odpowiedzi żadnego innego respondenta nie będą ujawnione.

- Twoje odpowiedzi zostaną poddane obróbce statystycznej w grupie danych połączonych z odpowiedziami innych respondentów. W wyniku takiej obróbki prowadzący badanie opublikują jedynie zbiorcze obserwacje co do czynników, które w ujęciu statystycznym mogą wpływać na skuteczność projektu.

\begin{tabular}{|r|l|c|c|c|c|c|c|c|}
\hline \multicolumn{1}{|c|}{ Stwierdzenia } & \multicolumn{3}{|c|}{ Odpowiedzi } \\
\hline 1 & $\begin{array}{l}\text { Ta osoba podchodzi do swojej pracy z profesjonalizmem } \\
\text { i zaangażowaniem. }\end{array}$ & 1 & 2 & 3 & 4 & 5 & 6 & 7 \\
\hline 2 & $\begin{array}{l}\text { Jesteśmy osobami, które w znacznym stopniu zaangażowały się } \\
\text { emocjonalnie w budowanie relacji w pracy pomiędzy nami. }\end{array}$ & 1 & 2 & 3 & 4 & 5 & 6 & 7 \\
\hline 3 & $\begin{array}{l}\text { Biorąc pod uwagę osiągnięcia tej osoby, nie widzę powodu, } \\
\text { by wątpić w jej kompetencje i przygotowanie do pracy. }\end{array}$ & 1 & 2 & 3 & 4 & 5 & 6 & 7 \\
\hline 4 & $\begin{array}{l}\text { Gdybym podzielit się swoimi problemami z tą osobą, wiem, } \\
\text { że zareagowałaby konstruktywnie i troskliwie. }\end{array}$ & 1 & 2 & 3 & 4 & 5 & 6 & 7 \\
\hline 5 & $\begin{array}{l}\text { Mogę polegać na tej osobie, wiem, że nie skomplikuje mojej pracy } \\
\text { przez własną niedbałą pracę. }\end{array}$ & 1 & 2 & 3 & 4 & 5 & 6 & 7 \\
\hline 6 & $\begin{array}{l}\text { Oboje odczulibyśmy stratę, gdyby jeden z nas został przeniesiony } \\
\text { i nie moglibyśmy już razem pracować. }\end{array}$ & 1 & 2 & 3 & 4 & 5 & 6 & 7 \\
\hline 7 & $\begin{array}{l}\text { Większość ludzi, nawet tych, którzy nie są bliskimi przyjaciółmi tej } \\
\text { osoby, ufają jej i darzą ją szacunkiem w pracy. }\end{array}$ & 1 & 2 & 3 & 4 & 5 & 6 & 7 \\
\hline 8 & $\begin{array}{l}\text { Mogę swobodnie rozmawiać z tą osobą o trudnościach, które mam } \\
\text { w pracy i wiem, że będę wystuchany/a. }\end{array}$ & 1 & 2 & 3 & 4 & 5 & 6 & 7 \\
\hline 9 & $\begin{array}{l}\text { Inni moi współpracownicy, którzy muszą współpracować } \\
\text { z tą osobą, uważają ją za godną zaufania. }\end{array}$ & 1 & 2 & 3 & 4 & 5 & 6 & 7 \\
\hline 10 & $\begin{array}{l}\text { Mamy relację opartą na otwartości. Możemy swobodnie dzielić się } \\
\text { zarówno naszymi pomysłami, jak i uczuciami i nadziejami. }\end{array}$ & 1 & 2 & 3 & 4 & 5 & 6 & 7 \\
\hline 11 & $\begin{array}{l}\text { Znając historię zawodową tej osoby, nie martwię się o wyniki i nie } \\
\text { muszę dokładnie monitorować jej pracy. }\end{array}$ & 1 & 2 & 3 & 4 & 5 & 6 & 7 \\
\hline
\end{tabular}

Źródło: opracowanie własne na podstawie D.J. McAllister, Affect-and-cognitionbased trust as foundations for interpersonal cooperation in organizations, „Academy of Management Journal” 1995, vol. 38(1), s. 24-59. 
Badaniem prezentowanym w tym opracowaniu objęto cztery zakończone projekty interimowe. Należy podkreślić, że pełny program badawczy czynników skuteczności projektu interimowego ma obejmować około 25 projektów, co oznacza dość długi czas realizacji badania, ponieważ badać można tylko zakończone projekty. Dopiero wówczas można bowiem ocenić ich efekty i znaczenie poszczególnych czynników na gruncie statystycznym. Jednocześnie wszyscy respondenci (w przypadku zaufania: klient, interim i zespół) są w tym momencie względnie obiektywni. Wszystkie dotychczasowe badania zostały przeprowadzone w 2019 roku.

Populacją badawczą są cztery projekty interimowe, których skrótowy opis znajduje się w tabeli 2. Opis musi być oszczędny i nie zawiera żadnych informacji (branża, wielkość firmy, czy też zatrudnienie) - kierując się założeniem unikania wpływu zakłóceń na odpowiedzi, autorzy wprowadzili zasadę anonimowości organizacji oraz respondentów.

Tabela 2. Charakterystyka projektów

\begin{tabular}{|c|c|c|c|c|c|c|c|}
\hline Projekt & $\begin{array}{c}\text { Obszar } \\
\text { funkcjo- } \\
\text { nalny }\end{array}$ & $\begin{array}{c}\text { Okres } \\
\text { trwania }\end{array}$ & $\begin{array}{l}\text { Wynik } \\
\text { - rodzaj }\end{array}$ & $\begin{array}{c}\text { Wynik } \\
\text { względem } \\
\text { celu }\end{array}$ & $\begin{array}{l}\text { Respon- } \\
\text { denci (IM } \\
\text { - interim } \\
\text { menedżer) }\end{array}$ & \multicolumn{2}{|c|}{ Instrument badawczy } \\
\hline \multirow[t]{3}{*}{$\# 1$} & \multirow[t]{3}{*}{ IT } & \multirow{3}{*}{$\begin{array}{c}6 \\
\text { miesięcy }\end{array}$} & \multirow{3}{*}{$\begin{array}{l}\text { Wdrożenie } \\
\text { systemu IT }\end{array}$} & \multirow{3}{*}{$\begin{array}{c}\text { Osiągnięty } \\
100 \%\end{array}$} & Klient & Kwestionariusz & Wywiad \\
\hline & & & & & $\mathrm{IM}$ & - & Wywiad \\
\hline & & & & & Zespót & Kwestionariusz & - \\
\hline \multirow[t]{3}{*}{$\# 2$} & \multirow{3}{*}{$\begin{array}{c}\text { Logisty- } \\
\text { ka }\end{array}$} & \multirow{3}{*}{$\begin{array}{c}12 \\
\text { miesięcy }\end{array}$} & \multirow{3}{*}{\begin{tabular}{|c} 
Wdrożenie \\
systemu \\
zarzą- \\
dzania \\
logistyką
\end{tabular}} & \multirow{3}{*}{$\begin{array}{c}\text { Osiągnięty } \\
100 \%\end{array}$} & Klient & Kwestionariusz & Wywiad \\
\hline & & & & & $\mathrm{IM}$ & - & Wywiad \\
\hline & & & & & Zespót & - & - \\
\hline \multirow[t]{3}{*}{$\# 3$} & \multirow{3}{*}{$\begin{array}{l}\text { Produk- } \\
\text { cja }\end{array}$} & \multirow{3}{*}{$\begin{array}{c}5 \\
\text { miesięcy }\end{array}$} & \multirow{3}{*}{$\begin{array}{c}\text { Transfer } \\
\text { technologii }\end{array}$} & \multirow{3}{*}{$\begin{array}{c}\text { Osiągnięty } \\
100 \%\end{array}$} & Klient & Kwestionariusz & Wywiad \\
\hline & & & & & $\mathrm{IM}$ & - & Wywiad \\
\hline & & & & & Zespót & Kwestionariusz & - \\
\hline \multirow[t]{3}{*}{$\# 4$} & \multirow[t]{3}{*}{ Finanse } & \multirow{3}{*}{$\begin{array}{c}6 \\
\text { miesięcy }\end{array}$} & \multirow{3}{*}{$\begin{array}{c}\text { Wdrożenie } \\
\text { systemu } \\
\text { raportowa- } \\
\text { nia finan- } \\
\text { sowego }\end{array}$} & \multirow{3}{*}{$\begin{array}{c}\text { Osiągnięty } \\
100 \%\end{array}$} & Klient & Kwestionariusz & Wywiad \\
\hline & & & & & $\mathrm{IM}$ & - & Wywiad \\
\hline & & & & & Zespót & Kwestionariusz & - \\
\hline
\end{tabular}

Źródło: opracowanie własne na podstawie wyników badań.

Proces badawczy rozpoczynało zapytanie skierowane do interim menedżera o zgodę na udział w badaniu, a dalej - poprzez niego - zapytanie o zgodę klienta korzystającego z usług interim menedżera, który z kolei decydował o włączeniu w badanie zespołu. W projekcie \#2 brakuje opinii zespołu, ponieważ pracownicy nie byli poinformowani o statusie interim menedżera, nie wiedzieli zatem o jego tymczasowej roli i klient nie chciał jeszcze przez jakiś czas ujawniać tego faktu. 
Po wykonaniu badań z wykorzystaniem powyższego kwestionariusza i opracowaniu uzyskanych wyników przeprowadzone zostały wywiady z klientami oraz interim menedżerami, które miały uzupełnić obraz znaczenia zaufania w realizacji projektu interimowego. Takie podejście badawcze jest zgodne z zawartymi w literaturze przedmiotu zaleceniami dotyczącymi badania zaufania (bardziej różnorodne podejście, rezygnacja $\mathrm{z}$ fragmentaryczności, wykorzystanie studium przypadku, mniej statyczne podejście dostosowane do dynamicznego, zmieniającego się w czasie konstruktu) ${ }^{29}$.

\section{Wyniki badań}

Instrument badawczy został zbudowany na siedmiostopniowej skali Likerta. Jedenaście pytań podzielono na grupę reprezentującą czynnik zaufania kognitywnego oraz grupę reprezentującą czynnik zaufania afektywnego ${ }^{30}$. Pytania mają charakter skierowany na występowanie zachowań lub odczuwanych emocji. Rysunki 3-5 wizualizują uzyskane wyniki badań dla trzech projektów, w których badanie było pełne (w projekcie \#2 nie ma opinii zespołu).

\section{Rozkład odpowiedzi Zaufanie Klient i Zespół Projekt \#1}

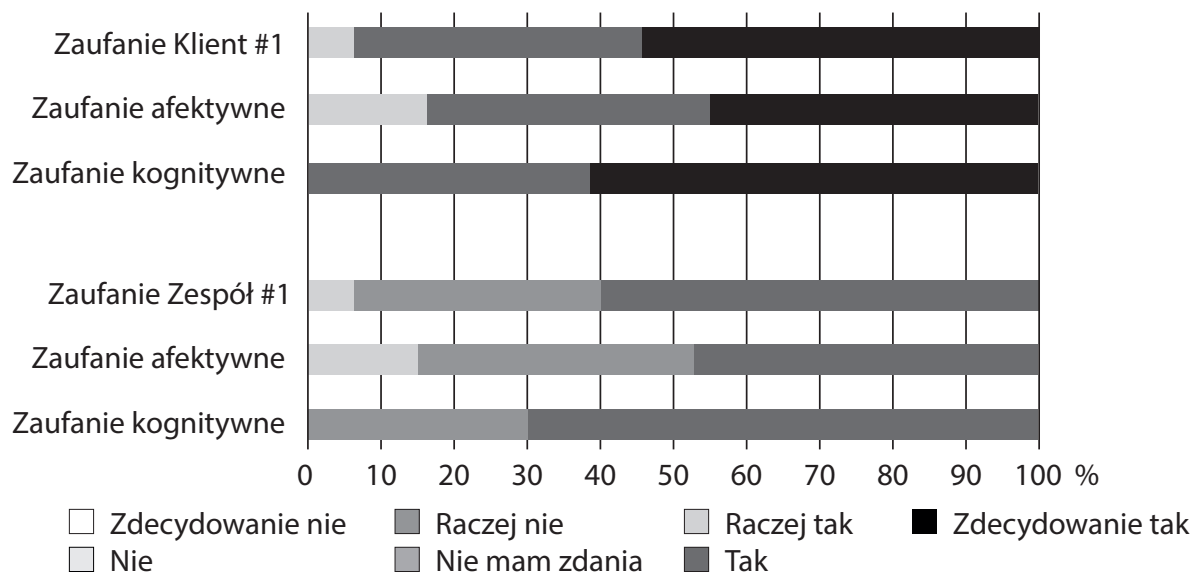

Rysunek 3. Poziom zaufania wobec interim menedżera - projekt \#1 Źródto: opracowanie własne na podstawie wyników badań.

29 D. Lewicka, K. Krot, D. Książek, Metodyczne aspekty...

30 Pogrupowanie odpowiedzi względem zaufania kognitywnego oraz afektywnego wymaga klucza do odkodowania kwestionariusza, który jest dostępny w: D.J. McAllister, Affect-and-cognition-based trust... 
Rozkład odpowiedzi Zaufanie Klient i Zespół Projekt \#3

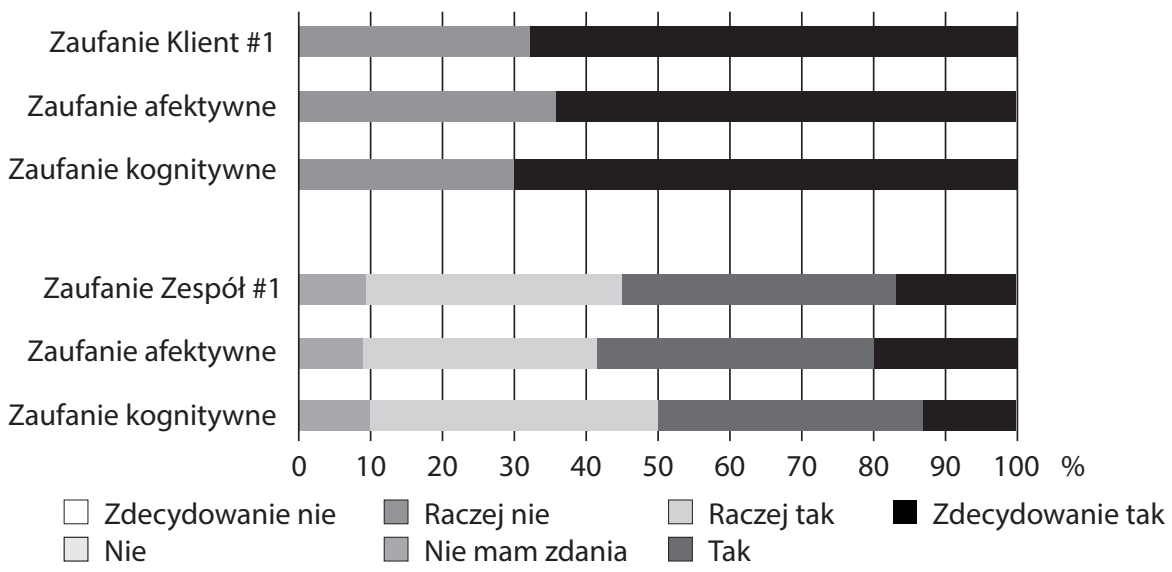

Rysunek 4. Poziom zaufania wobec interim menedżera - projekt \#3

Źródto: opracowanie własne na podstawie wyników badań.

Rozkład odpowiedzi Zaufanie Klient i Zespół Projekt \#4

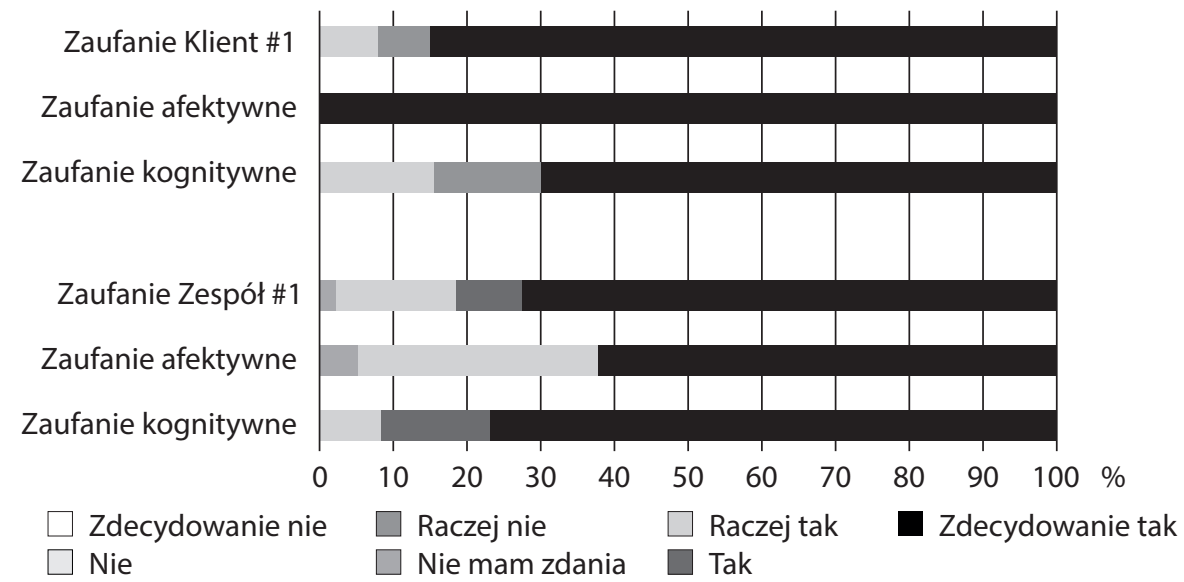

Rysunek 5. Poziom zaufania wobec interim menedżera - projekt \#4

Źródto: opracowanie własne na podstawie wyników badań.

Rozkład uzyskanych odpowiedzi zaufania dla zespołów \#1, \#3 i \#4 oraz dla klientów \#1, \#3, i \#4 pozwala zauważyć następujące wzorce zależności:

- we wszystkich wymienionych projektach rozkład odpowiedzi układa się w przypadku klienta na korzyść odpowiedzi „zdecydowanie tak” oraz „tak” w porównaniu do rozkładu odpowiedzi w przypadku zespołu, gdzie dominują odpowiedzi „tak” oraz „raczej tak” (z wyjątkiem projektu \#4); 
- powyższa obserwacja powtarza się zarówno na poziomie całej kategorii zaufania, jak i na poziomie czynników: zaufanie kognitywne i zaufanie afektywne;

- w rezultacie zaufanie w przypadku klienta jest istotnie większe niż w przypadku zespołu (od tego wzorca zależności różnią się odpowiedzi w zespole \#4). Opierając się na danych z wywiadów strukturyzowanych, z zastrzeżeniem wstępnego charakteru wyników w niniejszym artykule, wydaje się, że źródło tych różnic w projektach \#1 oraz \#3 może znajdować się w paru wymiarach relacji interim menedżera i klienta. Jeden z nich to wymiar czasu - klient wcześniej niż zespół rozpoczyna kontakt $\mathrm{z}$ interim menedżerem, odbywa się on bowiem już na etapie rekrutacji. Drugi z tych wymiarów wiąże się z wyraźnie wyższym poziomem zaufania kognitywnego - klient na etapie rekrutacji ma dostęp do życiorysu oraz referencji od poprzednich klientów.

Wymiary te mają zastosowanie także do projektu \#4, jednakże tu zaufanie kognitywne oraz afektywne dla klienta i zespołu są nie tylko zbliżone w ramach odpowiedzi dla projektu \#4, ale również daje się zauważyć wyższy poziom zaufania klienta w porównaniu z projektami \#3 i \#1. Opierając się na danych z wywiadów strukturyzowanych, wydaje się, że źródło tych różnic ma korzenie głównie w odrębnym charakterze projektu, który dotyczył obszaru finansowego. Zespół był więc bardziej jednorodny niż w przypadku projektów na przykład produkcyjnych, a kontakt z klientem częstszy.

Rozkład uzyskanych wyników zaufania kognitywnego w relacji do wyników zaufania afektywnego i w ramach kategorii skuteczności projektu interimowego, jaką jest zaufanie, pozwala zauważyć następujące wzorce zależności (rysunek 6):

- w przypadku klienta we wszystkich projektach zaufanie kognitywne jest najwyższe (projekt \#4 oraz projekt \#1) lub też pozostaje w wąskim zakresie wartości z zaufaniem afektywnym (projekt \#3 i projekt \#2);

- podobnie w przypadku zespołu: we wszystkich projektach (oprócz projektu \#2) zaufanie kognitywne jest najwyższe (projekt \#1 oraz projekt \#4) lub też pozostaje w wąskim zakresie wartości z zaufaniem afektywnym (projekt \# 3).

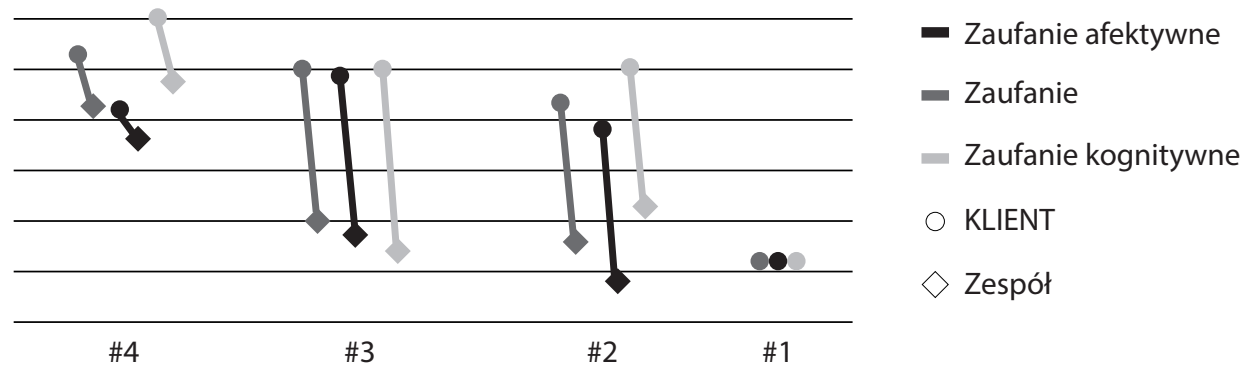

Rysunek 6. Statystyki deskryptywne zaufania kognitywnego oraz afektywnego Źródto: opracowanie własne na podstawie wyników badań. 
Łącząc obserwacje statystyk deskryptywnych (badanie instrumentem dla klienta oraz zespołu - rysunki 7 i 8) z wynikami wywiadów strukturyzowanych (z klientem oraz z interim menedżerem), zauważyć można następujące zależności:

- jeżeli transfer wiedzy do zespołu pozostaje w związku z poziomem zaufania, to poziom zaufania kognitywnego zdaje się wpływać na poziom wiedzy silniej niż poziom zaufania afektywnego (rysunki 7 i 8);

- poziom zaufania afektywnego wydaje się umożliwiać taką psychodynamikę procesów społecznych, jakie zachodzą pomiędzy interim menedżerem a zespołem, która może sprzyjać transferowi wiedzy (rysunek 8 oraz wywiady strukturyzowane); w przypadku projektów \#1 oraz \#3 taka zależność - jeśli występuje - wydaje się mieć mniejsze odchylenia niż w projekcie \#4; zbyt mała ilość danych nie pozwala rozstrzygnąć tej obserwacji na gruncie wnioskowania statystycznego (średniej oraz odchylenia standardowego);

- psychodynamika procesów społecznych związanych z wynikami transferu wiedzy do organizacji być może działa w pozytywnej pętli kauzacyjnej z zaufaniem, zwłaszcza wpływa uwiarygadniająco na postrzeganie interim menedżera jako eksperta przez klienta (rysunek 7 oraz wywiady strukturyzowane); być może dzięki temu, wraz z kolejnymi krokami budowania nowej wiedzy podczas trwania projektu, systematycznie rośnie zaufanie w relacji klient - interim menedżer (wnioski z wywiadów strukturyzowanych z klientami).

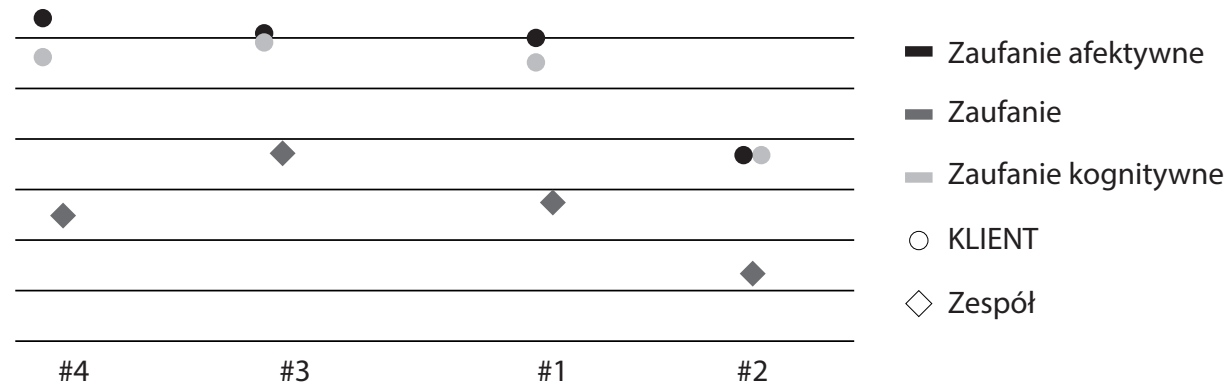

Rysunek 7. Deskryptywne statystyki zaufania kognitywnego i afektywnego klienta oraz poziomu wiedzy zespołu

Źródło: opracowanie własne na podstawie wyników badań.

Zestawiając wyniki dla wszystkich trzech kategorii czynników skuteczności projektu interimowego (rysunek 9), zauważyć można powtarzalny wzorzec rozkładu wyników badania. Wartości dla kryterium zaufania są najwyższe - projekt \#2 reprezentuje najniższe, lecz nawet tu wyniki dla zaufania są istotnie wysokie. 
Wydaje się, że bez wysokiego poziomu zaufania skuteczność władzy byłaby osłabiona, co mogłoby zmniejszyć wyniki dla transferu wiedzy do organizacji. Ten wniosek wydaje się szczególnie istotny w przypadku wyników uzyskanych dla zespołów pracujących bezpośrednio z interim menedżerami w projekcie (tylko dla projektów \#1, \#3, \#4). Wyniki badania władzy i wiedzy są identyczne dla projektów \#3 oraz \#4, natomiast wyniki dla projektu \#1 zawierają się w wąskim interwale wartości.

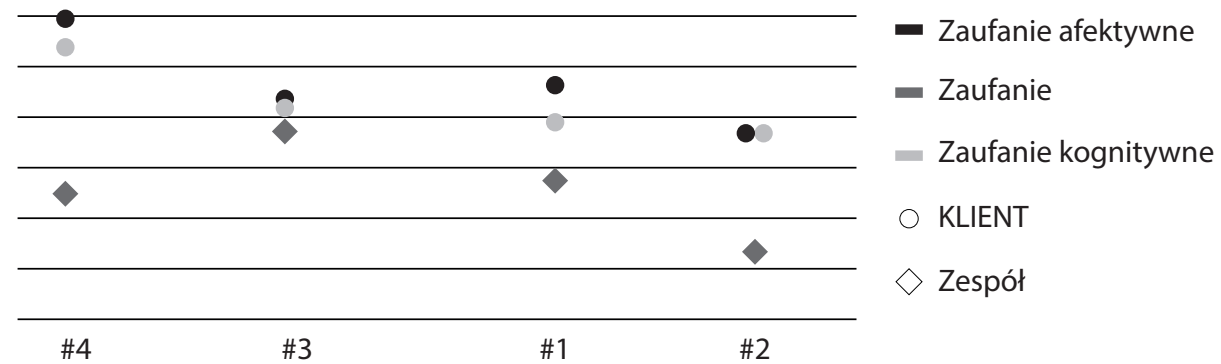

Rysunek 8. Deskryptywne statystyki zaufania kognitywnego i afektywnego zespołu oraz poziomu wiedzy zespołu

Źródło: opracowanie własne na podstawie wyników badań.

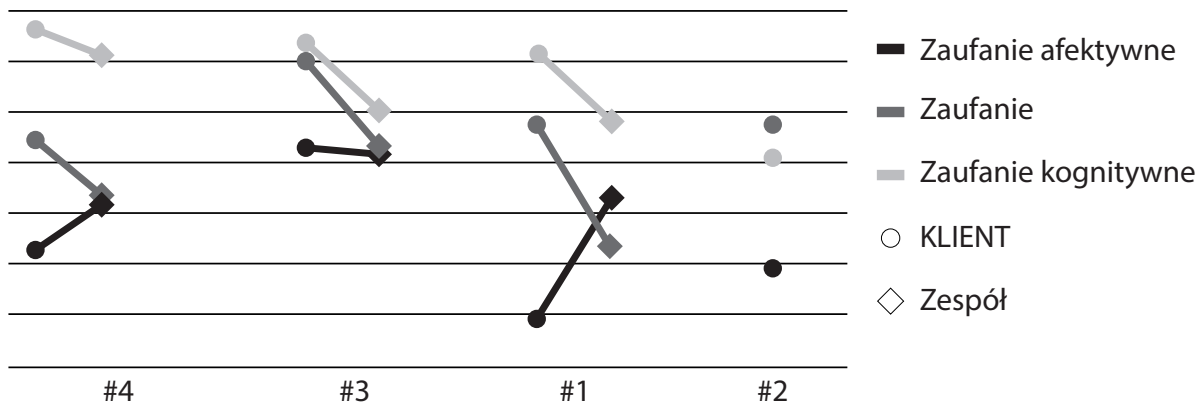

Rysunek 9. Statystyki deskryptywne dotyczące czynników skuteczności projektu interimowego

Źródto: opracowanie własne na podstawie wyników badań.

\section{Zakończenie}

Przedstawione badanie nawiązuje do wskazywanych kierunków badań w zakresie zaufania, zwłaszcza jako elementu pośredniczącego między dwoma pozornie sprzecznymi oczekiwaniami wobec organizacji: ciągłą otwartością na zmiany a przewidywalnością, pewnością i stałością, a także zaufania w zespołach 
projektowych, szczególnie w relacjach przełożony - podwładny ${ }^{31}$. Luka badawcza w obszarze zaufania w odniesieniu do interim management została jedynie zaakcentowana. Dla zamknięcia tej luki autorzy zastosowali takie instrumenty badawcze, jak:

- kwestionariusze, które wypełniane są przez klienta oraz członków zespołu w organizacji, współpracujących w projekcie bezpośrednio z interim menedżerem,

- wywiady strukturyzowane z klientem oraz z interim menedżerem, oddzielnie na podstawie wyników statystyk deskryptywnych i wizualizacji uzyskanych na bazie danych zebranych w kwestionariuszach.

Wstępne wyniki uzyskane na populacji czterech projektów interimowych pozwalają na sformułowanie wniosków co prawda ostrożnych, lecz wskazujących na możliwość występowania zaobserwowanego przez statystyki deskryptywne powtarzalnego rozkładu zależności między kategoriami czynników skuteczności projektu interimowego, czyli zaufaniem, władzą oraz wiedzą. Dzięki temu autorzy uzyskali potwierdzenie indukcyjne przyjętych empirycznie założeń dotyczących zaufania, władzy i wiedzy jako tych, które mogą mieć wpływ na skuteczność projektów interimowych. Istnieje w związku z tym potrzeba zweryfikowania w przyszłości wstępnych obserwacji przez wyniki wnioskowania statystycznego w kolejnych badaniach na kumulatywnej populacji około 25 projektów, co zapewniłoby prawidłowy poziom ufności statystycznej. Dotychczas populacja badawcza objęła tylko cztery projekty interimowe. Bez kontynuowania badań nie można jeszcze podejmować szerszych działań szkoleniowych lub rozwojowych wśród interim menedżerów czy też działań popularyzujących w Polsce interim management wśród klientów.

Powyższe wnioski, aczkolwiek wstępne i ostrożne, wskazują na potrzebę kontynuowania badań zarówno przez autorów, jak i przez kolejne zespoły badaczy, którzy mogliby użyć instrumentów oraz metodyki badawczej zastosowanych przez autorów niniejszego artykułu. Pozwoliłoby to zebrać kolejne dane, których ilość umożliwiłaby zamknięcie luki badawczej na gruncie wnioskowania statystycznego.

31 D. Lewicka, K. Krot, D. Książek, Metodyczne aspekty... 
Bibliografia

Arnott D., Research on Trust: A Bibliography and Brief Bibliometric Analysis of the Special Issue Submissions, „European Journal of Marketing” 2007, vol. 41(9/10), s. 1203-1240.

Bauer P. C., Freitag M., Measuring Trust, Chapter prepared for the Oxford Handbook of Social and Political Trust, Edited by Eric M. Uslaner, Oxford University Press, Oxford 2016, https://pa pers.ssrn.com/sol3/papers.cfm?abstract_id=2852755 (dostęp: 10.03.2019).

Bruns J., Kabst R., Interim-management: A paradox for leadership research?, „Management Revue" 2005 , vol. 15, s. 512-524.

Drabarek A., Zaufanie jako podstawowa wartość przestrzeni publicznej w wymiarze lokalnym, „Studies in Global Ethics and Global Education” 2014, no. 2, s. 3-11.

Eurofound, New forms of employment, Publications Office of the European Union, Luxembourg 2015, eurofound.link/ef1461 (dostęp: 20.10.2019).

Eurofound, Overview of new forms of employment - 2018 update, Publications Office of the European Union, Luxembourg 2018, eurofound.link/ef18050 (dostęp: 20.10.2019).

Gaczek P., Leszczyński G., Zieliński M., Afektywne a kalkulatywne zaufanie przed nawiqzaniem relacji biznesowych, „Handel Wewnętrzny” 2018, nr 3(374), s. 127-137.

Glaser B.G., Strauss A.L., Odkrywanie teorii ugruntowanej. Strategie badania jakościowego, Zakład Wydawniczy Nomos, Kraków 2009.

Handfield R.B., Betchel Ch., Trust, power, dependence, and economics: can SCM research borrow paradigms? „International Journal of Integrated Supply Management” 2004, vol. 1(1), s. 3-32.

Hardin R., Zaufanie, Wydawnictwo Sic!, Warszawa 2009.

Inkson K., Heising A., Rousseau D.M., The interim manager: Prototype of the 21st-century worker?, „Human Relations” 2001, vol. 54, no. 3, s. 259-284.

Interim Management w Polsce. Raport z badania zrealizowanego w 2018 roku, Stowarzyszenie Interim Managers, Warszawa 2019, http://stowarzyszenieim.org/public/www/media/File /2019/Raport\%20z\%20badania\%20rynu\%20interim\%20management\%202019.pdf (dostęp: 27.01.2020).

Isidor R., Schwens C., Kabst R., Interim management utilization, firm flexibility and its impact on firm performance, „International Journal of Human Resources Development and Management" 2014, vol. 14, no. 4, s. 174-186.

Kim T.-Y., Wang J., Chen J., Mutual trust between leader and subordinate and employee outcomes, „Journal of Business Ethics” 2018, vol. 149, issue 4, s. 945-958, https://www.researchgate .net/publication/294674500_Mutual_Trust_Between_Leader_and_Subordinate_and_Em ployee_Outcomes (dostęp: 22.12.2019).

Lewicka D., Krot K., Książek D., Metodyczne aspekty badania zaufania w naukach o zarządzaniu, „Zeszyty Naukowe Uniwersytetu Ekonomicznego w Krakowie” 2016, nr 7(955), s. 41-56.

Lewicki R.J., Tomlinson E.C., Gillespie N., Models of interpersonal trust development: Theoretical approaches, empirical evidence, and future directions, „Journal of Management” 2006, no. 32(6), s. 991-1022.

Łobos K., Mazur K., Wskaźniki zaufania w badaniach nad zaufaniem międzyorganizacyjnym, „Finanse, Rynki Finansowe, Ubezpieczenia” 2016, nr 1(79), s. 809-817, https://wneiz.pl/na uka_wneiz/frfu/79-2016/FRFU-79-809.pdf (dostęp: 7.09.2019).

McAllister D.J., Affect-and-cognition-based trust as foundations for interpersonal cooperation in organizations, „Academy of Management Journal” 1995, vol. 38(1), s. 24-59.

McEvily B., Tortoriello M., Measuring Trust in Organizational Research: Review and recommendations, „Journal of Trust Research” 2011, vol. 1(1),, s. 23-63, https://www.tandfonline.com/doi /pdf/10.1080/21515581.2011.552424?needAccess=true (dostęp: 23.11.2019). 
Metodyka Interim Management, Stowarzyszenie Interim Managers, Warszawa 2014.

Robbins S.P., Judge T.A., Organizational Behavior, 17th Edition, Pearson Education Limited, Edinburgh Gate, Harlow 2017.

Schilke O., Cook K.S., A cross-level process theory of trust development in interorganizational relationships, „Strategic Organization” 2013, no. 11(3), s. 281-303.

Skowron-Mielnik B., Bądzio M., Interim management jako forma doskonalenia biznesowego i zawodowego, „Zeszyty Naukowe Politechniki Śląskiej”, seria „Organizacja i Zarządzanie” 2016, z. 97, s. 449-460.

Weerd M. de, The knowledge gap of interim management, Paper presented at $5^{\text {th }}$ IBA Bachelor Conference 2015, July, 2nd, University of Twente, The Faculty of Behavioural, Management of Social Sciences, Enschede, The Netherlands, https://essay.utwente.nl/67386/1/de\%20 Weerd_BA_Management\%20\%26\%20Governance.pdf (dostęp: 9.01.2020).

Zenger J., Folkman J., The 3 Elements of Trust, „Harvard Business Review” 2019, February 5, https://hbr.org/2019/02/the-3-elements-of-trust (dostęp: 28.01.2020).

Zieliński M., Zaufanie w relacjach business-to-business. Perspektywa dynamiczna, Wydawnictwo Uniwersytetu Ekonomicznego w Poznaniu, Poznań 2019.

\section{Streszczenie}

Celem artykułu jest zdefiniowanie pojęcia, jakim jest zaufanie, w kontekście jego roli w realizacji i osiąganiu efektów projektu interimowego. Zaufanie jest jedną z trzech kategorii czynników skuteczności (obok wiedzy i władzy), przyjętych przez autorów w ramach koncepcji badań nad skutecznością interim managementu. W badaniu zaufania przyjęto jego dwa aspekty: kognitywny i afektywny, a metodyka badawcza oparta została na teorii ugruntowanej (cztery projekty interimowe). Pytania badawcze skierowane zostały do klienta/decydenta (kwestionariusz oraz wywiad), interim menedżera (wywiad) oraz zespołu współdziałającego z interim menedżerem (kwestionariusz). Wyniki wskazują na kluczowe znaczenie zaufania jako warunkującego dwie pozostałe kategorie czynników.

Słowa kluczowe: interim management, zaufanie kognitywne i afektywne, skuteczność

Trust as an effectiveness factor in interim management projects

\section{Abstract}

This article aims to define the concept of trust and the role it plays in implementing interim management (IM) projects and achieving results. Trust is one of three categories of effectiveness factors (next to knowledge and power) adopted for the purposes of our research on the effectiveness of IM. In this study two aspects of trust are explored: cognitive and affective. The research methodology is founded on a well-established grounded theory supported by systematically collected empirical data (four IM projects). Our respondents included clients/decision makers (a questionnaire and an interview), interim managers (an interview) and teams that cooperated with them (a questionnaire). The study shows that trust is significant in determining the other two categories of effectiveness factors in IM projects.

Keywords: interim management, cognitive and affective trust, effectiveness 